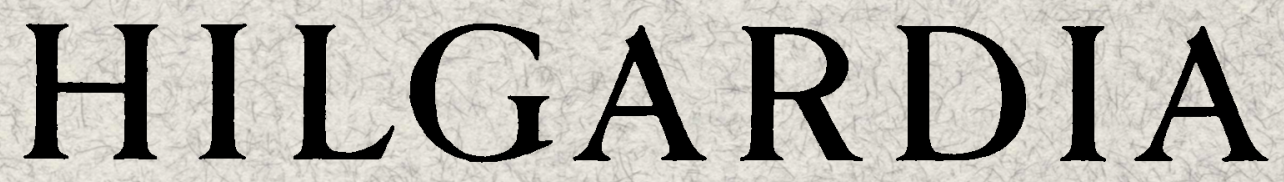

A Journal of Agricultural Science Published by the California Agricultural Experiment Station

\title{
GERMINATION OF SEEDS FROM CARROT, LETTUCE, AND PEPPER PLANIS GROWN UNDER SEVERE NUTRIENT DEFICIENCIES
}

\author{
JAMES F. HARRINGTON
}

UNIVERSITY OF CALIFORNIA · BERKELEY, CALIFORNIA 
Plants of carrot, lettuce, and pepper were grown in sand cultures receiving either a complete nutrient solution or one deficient in $\mathrm{N}, \mathrm{P}, \mathrm{K}$, or Ca. An effort was made to produce severe deficiency, but not to a point at which no seeds would be produced.

Plants showed various deficiency symptoms, including necrosis of the growing tips, with calcium deficiency, and necrotic spots along the leaf margins in the case of potassium deficiency.

Seed yields were always depressed by low N, P, K, or Ca treatments. Percentage of normal seeds was depressed by low $\mathrm{N}, \mathrm{K}$, or Ca, but not by low $P$.

At harvest, seeds from low $\mathbf{N}$ and $\mathbf{P}$ treatments usually showed the same germination as that of seeds receiving complete solution. However, $\mathrm{K}$ deficiency resulted in lower germination in some experiments, as did $\mathrm{Ca}$ deficiency in carrots and peppers.

In storage, seeds from low $\mathrm{K}$ and $\mathrm{Ca}$ treatments declined in germination faster than did seeds from the complete-solution treatments. 


\section{GERMINATION OF SEEDS FROM CARROT, LETTUCE, AND PEPPER PLANTS GROWN UNDER SEVERE NUTRIENT DEFICIENCIES ${ }^{1}$}

\section{JAMES F. HARRINGTON ${ }^{2}$}

\section{INTRODUCTION}

THE EFFECTS of mineral deficiencies on the growth and yield of crops and on yield, weight, and composition of grain and seed have been examined extensively. Yet few papers have reported, even incidentally, the effects of mineral deficiencies on germination of seed. Nevertheless, texts and other sources frequently mention the value of one mineral or another in assuring high germination.

Hartwell $(1932)^{3}$ included 389 references in an extensive review of research on the influence of fertilizers on crop quality. Many of those references described the influence of fertilizers on the chemical composition of the seed (including protein, starch, and oil content) as well as on kernel weight and weight per bushel. Resultant seed germination, however, was not mentioned.

Since Hartwell's review, a few papers have reported on the germination of seed from crops grown at different fertility levels.

Schudel (1952) found that, in an experimental field, onion seed yields ranged from 632 pounds per acre, under heavy fertilization with nitrogen, phosphorus, potassium, calcium, and sulfur, to 318 pounds per acre without fertilization. Respective germinations were 98 per cent and 95 per cent, with no significant germination differences among any of the treatments. Hawthorn and Pollard (1956) found that the viability of lettuce seed from their fertility plots was unaffected by either nitrogen or phosphorus levels.

James and Bancroft (1951) compared two levels of phosphorus, potassium, and calcium in producing crimson clover seed. The percentage of hard seeds was decreased by high potassium and increased by high calcium, but germination was unaffected by nutritional differences.

\footnotetext{
${ }^{1}$ Submitted for publication November 10, 1959.

2 Professor of Vegetable Crops and Olericulturist in the Experiment Station, Davis.

${ }^{3}$ See "Literature Cited" for citations referred to in the text by author and date.
} 
Pendleton (1954) more than doubled the yield of sugar beet seed with nitrogen, concurrently increasing germination from 86 to 92 per cent. Added phosphorus left seed yield unaffected, but further increased germination to 94 per cent (a difference of 7.7 per cent being significant at odds of 19:1). Iwata and Eguchi (1958) found that low phosphorus reduced seed yield and size, and seedling vigor of Chinese cabbage, but did not affect total germination, while low potassium reduced seed yield but did not affect seed size, vigor, or total germination. In further work, Eguchi (1960) found no effect of nitrogen on germination of Chinese cabbage, but a slight though significant increase in germination of seeds from cabbage plants side-dressed with nitrogen (98.4 per cent versus 95.9 per cent; L.S.D. at 99:1, 2.3 per cent).

Person and Berger (1950) found that phosphorus in nutrient solution cultures had little or no effect on germination of pea seeds, although rate of germination was slower in seeds from plants grown with low phosphorus. Seeds from magnesium-deficient plants, in contrast, germinated only half as well as seeds from plants adequately supplied with magnesium (42 per cent versus 80 per cent).

Fox and Albrecht (1957) reported that wheat seeds high in total nitrogen emerged from the soil more rapidly.

In summary, both fertilizer tests and nutrition experiments indicate that germination of harvested seeds is affected very little by the level of nitrogen, phosphorus, potassium, or calcium supplied to the plant. In the experiments cited, however, none of the nutritional deficiencies was extremely severe.

This paper discusses how germination is affected by deficiencies of nitrogen, phosphorus, potassium, or calcium so severe that only a few seeds are produced per plant.

\section{MATERIALS AND METHODS}

In all experiments, 3-gallon, glazed crocks with drain holes were used. They were filled with washed, white Monterey fine sand. Between experiments the sand from each crock was screened, washed, and replaced in the same crock. Each crock was used for the same nutrient-deficient solution throughout all experiments.

Hoagland's (1950) solutions were used: complete, $-\mathrm{N},-\mathrm{P},-\mathrm{K}$, and -Ca. Each week the crocks were thoroughly leached three times with distilled water, with complete draining after each leaching. One liter of the proper nutrient solution was then poured over the sand and allowed to drain into a covered black container. Each day the volume in the container was brought up to the liter mark with distilled water, and the solution was again poured over the sand.

Two methods were used in producing nutrient deficiencies in the plants under study.

Method 1. At the start, germinating seed and young plants were given a complete nutrient solution. At various stages in the growth of the plants, the complete solution was changed to a solution deficient in the nutrient being tested. Thus, the earlier a nutrient was removed, the more severe was the plant's deficiency. However, removing a nutrient too early killed the 
plants or resulted in such weak growth that no seeds were produced. Removing a nutrient too late produced a plant with no deficiency symptoms and with growth and seed yield comparable with those of plants receiving the complete solution.

Method 2. With this method, a plant received, throughout growth, a mixture of deficient solution and complete solution. In this paper a mixture is expressed as a proportion, with deficient portions always mentioned first. Thus a $-\mathrm{N} 3: 1$ solution is a solution containing three parts Hoagland's $-\mathrm{N}$ solution and one part complete solution. To express these nutrients in terms of millimoles per liter of solution, the nitrogen varied from $15 \mathrm{mM}$ in Hoagland's complete solution to $0.23 \mathrm{mM}$ in the $63: 1-\mathrm{N}$ solution; phosphorus, from $1 \mathrm{mM}$ in the complete solution to $0.0078 \mathrm{mM}$ in the 127:1 -P solution; potassium, from $6 \mathrm{mM}$ in the complete solution to $0.094 \mathrm{mM}$ in the $63: 1-\mathrm{K}$ solution; and calcium, from $5 \mathrm{mM}$ in the complete solution to $0.078 \mathrm{mM}$ in the $63: 1$ - Ca solution.

The terms $-\mathrm{N},-\mathrm{P},-\mathrm{K}$, and $-\mathrm{Ca}$ are used throughout this paper, but it must be remembered that the plants received some of the nutrient in question, either during early growth or, in the second method, in the nutrient solution mixture.

The plants were intentionally grown at nutritional levels so low that some died or were so weak that they failed to produce seed. Such extreme deficiencies are seldom if ever encountered in nature.

Obviously, because of the aim of the experiments, few of the data could be statistically analyzed, even though many of the experiments were set up with either two or five single-plant replications. In addition, the percentage of germination of the two or 17 or even 59 seeds produced by some plants could not justifiably be analyzed statistically in comparison with the germination of several hundred seeds obtained from other, nondeficient plants.

Morphological symptoms of the different deficiencies were evident in all experiments. With extreme deficiencies of $\mathrm{N}, \mathrm{P}, \mathrm{K}$, or $\mathrm{Ca}$, the plants produced no seed, or even died. Symptoms of nitrogen deficiency were a stunting of the plant and yellowing of the leaves. Phosphorus deficiency was expressed by stunting of the plants, which were dark green, and, with carrots, purpling of the midribs of the leaves. Potassium deficiency symptoms were necrotic spots around the leaf margins. Pepper fruits on low-potassium plants turned orange at maturity, rather than red. The most obvious expression of calcium deficiency was death of the growing points. Most of the pepper fruits on calcium-deficient plants developed blossom-end rot.

The methods used and the data obtained from each experiment with each crop are included together, with brief mention of results. In the discussion (p. 231) the results are presented on a basis of response to the different deficiencies, since the purpose of the experiment was to determine their effect on seed germination. 


\section{Experiments with Carrots}

Red Core Chantenay carrot seed (95 per cent germination) from the PietersWheeler Seed Company was used.

First Experiment, 1949-1950. On May 5, 1949, 30 carrot seeds were sown in each crock. While in the young plant stage, the plants were thinned to three per crock. To induce flower formation, the roots were dug and topped on September 1, and stored at $5^{\circ} \mathrm{C}$ until December 1 , when the best root from each crock was replanted in the same crock, and the same nutrient treatment was continued.

\section{TABLE 1}

EFFECT OF COMPLETE, $-\mathrm{N},-\mathrm{P},-\mathrm{K}$, OR -CA NUTRIENT SOLUTIONS ON CARROTS AT HARVEST AND AFTER NINE YEARS' STORAGE

(1949-1950 Experiment)

\begin{tabular}{|c|c|c|c|c|c|c|}
\hline Treatment & $\begin{array}{l}\text { Weeks on } \\
\text { complete } \\
\text { solution }\end{array}$ & $\begin{array}{c}\text { Yield } \\
\text { per } \\
\text { plant }\end{array}$ & $\begin{array}{l}\text { Av. wt. } \\
100 \text { seeds }\end{array}$ & $\begin{array}{l}\text { Large- } \\
\text { heavy } \\
\text { seed }\end{array}$ & Wtd. germ. & $\begin{array}{l}\text { Nine-year } \\
\text { wtd. germ. }\end{array}$ \\
\hline Complete & $\begin{array}{l}60 \\
60 \\
60\end{array}$ & \begin{tabular}{r}
\multicolumn{1}{c}{$g m$} \\
61.80 \\
26.08 \\
7.50
\end{tabular} & $\begin{array}{l}m g \\
131 \\
202 \\
132\end{array}$ & $\begin{array}{c}\text { per cent } \\
96 \\
97 \\
94\end{array}$ & $\begin{array}{c}\text { per cent } \\
96 \\
87 \\
86\end{array}$ & $\begin{array}{c}\text { per cent } \\
1 \\
4 \\
4\end{array}$ \\
\hline$-\mathrm{N}$ & $\begin{array}{r}12 \\
8 \\
6\end{array}$ & $\begin{array}{l}2.18 \\
0.51 \\
0.00\end{array}$ & $\begin{array}{c}88 \\
67 \\
\ldots\end{array}$ & $\begin{array}{l}80 \\
88 \\
. .\end{array}$ & $\begin{array}{l}80 \\
66 \\
. .\end{array}$ & $\begin{array}{c}2 \\
0 \\
. .\end{array}$ \\
\hline$-P$ & $\begin{array}{r}12 \\
8 \\
6\end{array}$ & $\begin{array}{r}21.00 \\
6.63 \\
6.52\end{array}$ & $\begin{array}{l}139 \\
244 \\
182\end{array}$ & $\begin{array}{l}97 \\
83 \\
86\end{array}$ & $\begin{array}{l}63 \\
59 \\
86\end{array}$ & $\begin{array}{l}1 \\
4 \\
8\end{array}$ \\
\hline$-\mathrm{K}$ & $\begin{array}{r}12 \\
8 \\
6\end{array}$ & $\begin{array}{l}4.34 \\
0.00 \\
2.17\end{array}$ & $\begin{array}{l}145 \\
\ldots \\
113\end{array}$ & $\begin{array}{l}95 \\
. . \\
89\end{array}$ & $\begin{array}{l}92 \\
. \\
83\end{array}$ & $\begin{array}{c}0 \\
0 \\
0\end{array}$ \\
\hline$-\mathrm{Ca}$ & $\begin{array}{r}12 \\
8 \\
6\end{array}$ & $\begin{array}{r}12.65 \\
3.00 \\
0.21\end{array}$ & $\begin{array}{r}163 \\
188 \\
25\end{array}$ & $\begin{array}{r}93 \\
98 \\
0\end{array}$ & $\begin{array}{r}29 \\
21 \\
1\end{array}$ & $\begin{array}{l}0 \\
0 \\
0\end{array}$ \\
\hline
\end{tabular}

In the different treatments the nutrient solutions had been changed from complete to the minus solution on May 5 (start of experiment), May 20, June 17, July 1, or July 29. None of the roots from plants that received deficient solutions beginning on May 5 or May 20 was still alive after cold storage. Neither the plants receiving the $-\mathrm{N}$ solution beginning June 17 nor those receiving the $-\mathrm{K}$ solution beginning July 1 survived to maturity. The seed crops were harvested as they matured, between July 1 and July 27, 1950. They were allowed to dry two weeks before the seed was threshed and cleaned. The seed was divided first by passing it over a No. $1 / 16$ sereen (holes $1 / 16$ inch in diameter). Each of the resulting lots was then passed over a fanning mill to separate the light from the heavy seed. Thus, four classes were obtained: large-heavy, large-light, small-heavy, and small-light. The large-heavy class, as can be seen in table 1, included 80 to 98 per cent of the 
seed from any one plant. Samples of 100 seeds from each class from each treatment were weighed, and germination tests were conducted on each sample. The remaining seeds were then stored for nine years in a dry office at room temperature, and retested for germination.

Table 1 compares the three plants that received complete solution throughout with the plants that received complete solution 12, 8 , or 6 weeks before receiving solutions deficient in $\mathrm{N}, \mathrm{P}, \mathrm{K}$, or $\mathrm{Ca}$. The longer a plant received complete solution before being changed to a deficient solution, the higher was its seed yield.

TABLE 2

EFFECT OF COMPLETE, $-\mathrm{N},-\mathrm{P},-\mathrm{K}$, OR -CA NUTRIENT SOLUTIONS ON PERCENTAGE GERMINATION OF CARROT SEED AT HARVEST AND AFTER EIGHT YEARS' STORAGE

(1950-1951 Experiment)

\begin{tabular}{|c|c|c|c|}
\hline \multirow[b]{2}{*}{ Treatment } & \multirow[b]{2}{*}{ No. plants } & \multicolumn{2}{|c|}{ Germination } \\
\hline & & At harvest & $\begin{array}{c}\text { After } 8 \text { years' } \\
\text { storage }\end{array}$ \\
\hline & & per cent & per cent \\
\hline Complete. & 1 & 87 & 16 \\
\hline$-\mathrm{N} \ldots \ldots$ & 4 & 81 & 28 \\
\hline$-\mathrm{P}$ & 3 & 92 & 74 \\
\hline & 2 & 40 & 2 \\
\hline$-\mathrm{Ca}$ & 1 & 74 (51 seed) & .. \\
\hline
\end{tabular}

Second Experiment, 1950-1951. The second experiment, also with Red Core Chantenay carrots, was begun on July 27, 1950. The plants destined for each nutrient deficiency treatment received complete Hoagland's solution until the roots were removed for storage. They were stored at $5^{\circ} \mathrm{C}$ from November 1 to January 2, 1951, when they were replanted and the treatments were begun. This method was used to avoid the losses of roots during storage that occurred with the more severely deficient plants in the first carrot experiment. Unfortunately, all plants were killed in the greenhouse on an extremely hot day in late July, 1951. At that time some plants had mature seed in the first-order umbel. These were harvested on August 1, 1951. Germination tests were run soon after harvest, and again eight years later. Results are shown in table 2.

\section{Experiments with Lettuce}

In both experiments, a leaf-lettuce variety, Grand Rapids (Associated Seed Growers), was used. Ten seeds were sown in a ring around the center of a crock. At the two- to three-leaf stage, the plants were thinned to one plant per crock.

The first lettuce experiment was begun on November 3, 1953, and ended June 14, 1954. The second was started October 1, 1954, and ended April 26, 1955. These times were selected to avoid extreme heat in the greenhouse in the late spring and summer. 
The following deficiencies were tested:

1953

1954

PROPORTION MINUS : COMPLETE NUTRIENT

PROPORTION MINUS: COMPLETE NUTRIENT

$\begin{array}{lrllrrr}-\mathrm{N} & 7: 1 & 15: 1 & 31: 1 & 15: 1 & 31: 1 & 63: 1 \\ -\mathrm{P} & 15: 1 & 31: 1 & 63: 1 & 31: 1 & 63: 1 & 127: 1 \\ -\mathrm{K} & 15: 1 & 31: 1 & 63: 1 & 7: 1 & 15: 1 & 31: 1 \\ -\mathrm{Ca} & 15: 1 & 31: 1 & 63: 1 & 7: 1 & 15: 1 & 31: 1\end{array}$

The proportion of minus to complete nutrient was changed in 1954, as a result of experience in 1953, in an effort to create a nutrient deficiency as severe as possible yet permit development of some seeds to harvest.

At maturity the seeds were gently shaken off each plant as often as four times. The seeds from each harvest were kept separate for study of possible changes in the germination ability of the seeds as the plant aged. In the first lettuce experiment, death of the apical meristem of calcium-deficient plants prevented flowering and the development of seed.

TABLE 3

EFFECT OF COMPLETE, $-\mathrm{N},-\mathrm{P},-\mathrm{K}$, OR -CA NUTRIENT SOLUTIONS ON

PERCENTAGE GERMINATION OF LETTUCE SEED AT HARVEST AND

OF RED COTYLEDON AFTER FIVE YEARS' STORAGE

(1953-1954 Experiment)

\begin{tabular}{|c|c|c|c|c|}
\hline \multirow{2}{*}{ Treatment } & \multirow{2}{*}{$\begin{array}{l}\text { Ratio of deficient } \\
\text { to complete } \\
\text { nutrient in } \\
\text { solution }\end{array}$} & \multirow{2}{*}{$\begin{array}{c}\text { Germination } \\
\text { at harvest }\end{array}$} & \multicolumn{2}{|c|}{ After 5 years' storage } \\
\hline & & & $\underset{\text { germination }}{\text { Total }}$ & $\begin{array}{l}\text { Germination } \\
\text { red cotyl. }\end{array}$ \\
\hline Complete & $\ldots$ & $\begin{array}{c}\text { per cent } \\
100.0\end{array}$ & $\begin{array}{c}\text { per cent } \\
45.8\end{array}$ & $\begin{array}{c}\text { per cent } \\
35.8\end{array}$ \\
\hline$-\mathrm{N}$ & $\begin{array}{r}7: 1 \\
15: 1 \\
31: 1\end{array}$ & $\begin{array}{r}100.0 \\
99.8 \\
100.0\end{array}$ & $\begin{array}{r}19.8 \\
42.3 \\
35.4\end{array}$ & $\begin{array}{l}16.5 \\
39.5 \\
30.2\end{array}$ \\
\hline$-P$ & $\begin{array}{l}15: 1 \\
31: 1 \\
63: 1\end{array}$ & $\begin{array}{r}99.8 \\
99.7 \\
100.0\end{array}$ & $\begin{array}{l}51.2 \\
25.0 \\
42.8\end{array}$ & $\begin{array}{l}45.2 \\
22.2 \\
35.2\end{array}$ \\
\hline$-K$ & $\begin{array}{l}15: 1 \\
31: 1 \\
63: 1\end{array}$ & $\begin{array}{c}100.0 \\
\text { no seed } \\
94.0\end{array}$ & $\begin{array}{c}13.0 \\
\text { no seed } \\
\text { no seed }\end{array}$ & $\begin{array}{c}12.4 \\
\text { no seed } \\
\text { no seed }\end{array}$ \\
\hline$-\mathrm{Ca}$ & $\begin{array}{l}15: 1 \\
31: 1 \\
63: 1\end{array}$ & $\begin{array}{l}\text { no seed } \\
\text { no seed } \\
\text { no seed }\end{array}$ & $\begin{array}{l}\text { no seed } \\
\text { no seed } \\
\text { no seed }\end{array}$ & $\begin{array}{l}\text { no seed } \\
\text { no seed } \\
\text { no seed }\end{array}$ \\
\hline
\end{tabular}

First Experiment, 1953-1954. Table 3 shows that germination of the lettuce seeds from all treatments in the first lettuce experiment was nearly 100 per cent immediately after harvest, and poor after five years at room temperature.

The red cotyledon referred to in tables 3 and 4 indicates a physiological abnormality of the germinating lettuce seedling that increases in seeds stored at room temperature or higher (Dempsey and Harrington, 1951). All lettuce seedlings with red cotyledons, but otherwise normal, and with normal radi- 
cles, were considered germinated, but are also listed in the red cotyledon column.

Successive harvests from the same plant showed no differences in germination at harvest time nor in deterioration after five years of storage. The first, second, third, and fourth harvests showed 30, 34, 41, and 30 per cent germination, respectively, of which 26,29 , 39, and 24 per cent had red cotyledons. The average 100-seed-weight decreased from $204 \mathrm{mg}$ for control plants to $184 \mathrm{mg}, 175 \mathrm{mg}$, and $165 \mathrm{mg}$, respectively, for plants deficient in phosphorus, nitrogen, and potassium. Excluding the one potassium-deficient plant, a difference of $15.6 \mathrm{mg}$ was significant and a difference of 21.7 was

TABLE 4

EFFECT OF COMPLETE, $-\mathrm{N},-\mathrm{P},-\mathrm{K}$, OR -CA NUTRIENT SOLUTIONS ON PERCENTAGE GERMINATION OF LETTUCE SEED AT HARVEST AND OF RED COTYLEDON AFTER THREE AND FOUR YEARS' STORAGE (1954-1955 Experiment)

\begin{tabular}{|c|c|c|c|c|c|c|c|c|c|c|}
\hline \multirow{2}{*}{\multicolumn{2}{|c|}{ Treatment }} & \multicolumn{3}{|c|}{1955} & \multicolumn{3}{|c|}{1958} & \multicolumn{3}{|c|}{1959} \\
\hline & & $\begin{array}{l}\text { Seeds } \\
\text { tested }\end{array}$ & Germ. & $\begin{array}{l}\text { Red } \\
\text { cot. }\end{array}$ & $\begin{array}{l}\text { Seeds } \\
\text { tested }\end{array}$ & Germ. & $\begin{array}{l}\text { Red } \\
\text { cot. }\end{array}$ & $\begin{array}{l}\text { Seeds } \\
\text { tested }\end{array}$ & Germ. & $\begin{array}{l}\text { Red } \\
\text { cot. }\end{array}$ \\
\hline \multicolumn{2}{|c|}{ Complete...... } & 1,100 & $\begin{array}{c}\text { per cent } \\
99.2\end{array}$ & $\begin{array}{c}\text { per cent } \\
11.6\end{array}$ & 947 & $\begin{array}{c}\text { per cent } \\
98.0\end{array}$ & $\begin{array}{c}\text { per cent } \\
91.4\end{array}$ & 800 & $\begin{array}{c}\text { per cent } \\
75.6\end{array}$ & $\begin{array}{c}\text { per cent } \\
71.5\end{array}$ \\
\hline \multirow{2}{*}{\multicolumn{2}{|c|}{$\begin{array}{rr}-\mathrm{N} \quad \begin{array}{r}71 \ldots \ldots \\
15: 1 \ldots \ldots \\
31: 1 \ldots \ldots\end{array} \\
\\
\\
\text { Total or mean.. }\end{array}$}} & $\begin{array}{l}238 \\
200 \\
298\end{array}$ & $\begin{array}{l}99.5 \\
97.5 \\
99.6\end{array}$ & $\begin{array}{r}12.6 \\
8.5 \\
25.8\end{array}$ & $\begin{array}{r}99 \\
109 \\
48\end{array}$ & $\begin{array}{l}98.9 \\
89.8 \\
97.9\end{array}$ & $\begin{array}{l}39.4 \\
67.9 \\
79.1 \\
\end{array}$ & $\begin{array}{l}\cdots \\
\cdots \\
\cdots\end{array}$ & $\begin{array}{l}\cdots \\
\cdots \\
\cdots\end{array}$ & $\begin{array}{l}\ldots \\
\cdots \\
\cdots\end{array}$ \\
\hline & & 736 & 99.0 & 16.8 & 288 & 94.0 & 61.9 & $\ldots$ & $\ldots$ & $\ldots$ \\
\hline \multirow{2}{*}{\multicolumn{2}{|c|}{$\begin{array}{rr}-\mathrm{P} \quad 15: 1 \ldots \ldots \\
31: 1 \ldots \ldots \\
63: 1 \ldots \ldots \\
\\
\\
\text { Total or mean.. }\end{array}$}} & $\begin{array}{l}100 \\
600 \\
231\end{array}$ & $\begin{array}{l}99.0 \\
99.7 \\
93.0\end{array}$ & $\begin{array}{l}99.0 \\
53.5 \\
55.0\end{array}$ & $\begin{array}{r}19 \\
600 \\
20\end{array}$ & $\begin{array}{r}100.0 \\
93.8 \\
95.0\end{array}$ & $\begin{array}{l}78.9 \\
82.4 \\
85.0\end{array}$ & $\begin{array}{c}\ldots \\
500 \\
\ldots\end{array}$ & $\begin{array}{l}\ldots \\
72.0 \\
\ldots\end{array}$ & $\begin{array}{l}\ldots \\
72.0 \\
\ldots\end{array}$ \\
\hline & & 931 & 97.9 & 58.7 & 639 & 94.0 & 82.4 & 500 & 72.0 & 72.0 \\
\hline \multirow{2}{*}{\multicolumn{2}{|c|}{$\begin{array}{rr}-\mathrm{K} \quad 15: 1 \ldots \ldots \\
31: 1 \ldots \ldots \\
63: 1 \ldots \ldots\end{array}$}} & $\begin{array}{l}194 \\
200 \\
855\end{array}$ & $\begin{array}{r}100.0 \\
99.5 \\
98.7\end{array}$ & $\begin{array}{r}17.0 \\
7.5 \\
15.9\end{array}$ & $\begin{array}{l}300 \\
200 \\
800\end{array}$ & $\begin{array}{l}99.4 \\
75.5 \\
90.5\end{array}$ & $\begin{array}{l}89.6 \\
71.0 \\
87.2\end{array}$ & $\begin{array}{l}300 \\
103 \\
679\end{array}$ & $\begin{array}{r}67.7 \\
4.9 \\
31.1\end{array}$ & $\begin{array}{r}53.0 \\
4.9 \\
30.7\end{array}$ \\
\hline & & 1,249 & 99.0 & 14.7 & 1,300 & 90.3 & 85.3 & 1,082 & 38.6 & 34.3 \\
\hline \multirow{2}{*}{\multicolumn{2}{|c|}{$\begin{array}{rr}\text {-Ca } 15: 1 \ldots \ldots \\
31: 1 \ldots \ldots \\
63: 1 \ldots \ldots \\
\\
\\
\text { Total or mean. }\end{array}$}} & $\begin{array}{r}50 \\
435 \\
26\end{array}$ & $\begin{array}{r}98.0 \\
98.9 \\
100.0\end{array}$ & $\begin{array}{l}96.0 \\
51.5 \\
92.3\end{array}$ & $\begin{array}{l}\ldots \\
400 \\
\ldots\end{array}$ & $\begin{array}{l}\ldots \\
92.7 \\
\ldots\end{array}$ & $\begin{array}{l}\ldots \\
92.4 \\
\ldots\end{array}$ & $\begin{array}{c}\ldots \\
361 \\
\ldots\end{array}$ & $\begin{array}{l}\ldots \\
46.2 \\
\ldots .\end{array}$ & $\begin{array}{l}\ldots \\
45.1 \\
\ldots\end{array}$ \\
\hline & & 511 & 98.8 & 57.9 & 400 & 92.7 & 92.4 & 361 & 46.2 & 45.1 \\
\hline
\end{tabular}

highly significant. There was a trend toward smaller seeds as nitrogen deficiency increased. Weight per 100 seeds dropped from $169 \mathrm{mg}$ for plants receiving the $7: 1$ solution to $155 \mathrm{mg}$ for plants receiving the $31: 1$ solution. No trend was evident in seeds from phosphorus-deficient plants.

The average yield of seeds per plant was $15.43 \mathrm{gm}$ for plants receiving the complete solution, $6.31 \mathrm{gm}$ for the potassium-deficient plants, $3.97 \mathrm{gm}$ for the nitrogen-deficient plants, and $3.45 \mathrm{gm}$ for the phosphorus-deficient plants. 
Second Experiment, 1954-1955. In the second experiment, respective seed yields per plant for the plants receiving complete, low nitrogen, low phosphorus, low potassium, and low calcium solutions were $6.92,0.23,0.68,1.68$, and $0.82 \mathrm{gm}$, and the average 100 -seed-weights were $137,120,143,137$, and $164 \mathrm{mg}$. Table 4 gives the germination of seeds at harvest and after three and four years at room temperature. Seeds from $-\mathrm{K}$ and $-\mathrm{Ca}$ plants deteriorated in germination more rapidly than did seeds grown with complete solution.

TABLE 5

EFFECT OF COMPLETE, $-\mathrm{N},-\mathrm{P},-\mathrm{K}$, OR -CA NUTRIENT SOLUTIONS ON PEPPERS

(1951-1952 Experiment)

\begin{tabular}{|c|c|c|c|c|c|c|c|c|}
\hline \multirow{2}{*}{ Treatment } & \multirow{2}{*}{$\begin{array}{c}\text { Wks. of } \\
\text { complete } \\
\text { before } \\
\text { minus }\end{array}$} & \multirow{2}{*}{$\begin{array}{c}\text { No. of } \\
\text { fruits } \\
\text { har- } \\
\text { vested }\end{array}$} & \multirow{2}{*}{$\begin{array}{c}\text { No. } \\
\text { seeds } \\
\text { per } \\
\text { fruit }\end{array}$} & \multicolumn{2}{|c|}{ Normal } & \multicolumn{2}{|c|}{ Abnormal } & \multirow{2}{*}{$\begin{array}{c}\text { Total } \\
\text { per cent } \\
\text { germ. }\end{array}$} \\
\hline & & & & $\begin{array}{l}\text { Per cent } \\
\text { of total }\end{array}$ & $\begin{array}{l}\text { Per cent } \\
\text { germ. }\end{array}$ & $\begin{array}{l}\text { Per cent } \\
\text { of total }\end{array}$ & $\begin{array}{l}\text { Per cent } \\
\text { germ. }\end{array}$ & \\
\hline \multirow[t]{5}{*}{ Complete. } & .. & 2 & 468 & 53 & 79 & 13 & 25 & 46 \\
\hline & .. & 2 & 458 & 80 & 78 & 14 & 29 & 67 \\
\hline & .. & 4 & 230 & 78 & 76 & 1 & 56 & 60 \\
\hline & .. & 2 & 224 & 84 & 92 & 9 & 69 & 84 \\
\hline & .. & 2 & 282 & 72 & 90 & 19 & 46 & 74 \\
\hline Average or total. & & 12 & 315 & 72.4 & 81.4 & 10.6 & 37.1 & 63.0 \\
\hline \multirow[t]{4}{*}{$-\mathrm{N}$} & 5 & 0 & $\ldots$ & .. & .. & . & .. & .. \\
\hline & 6 & 1 & 1 & 100 & 100 & 0 & .. & 100 \\
\hline & 7 & 1 & 94 & 55 & 100 & 0 & .. & 56 \\
\hline & 9 & 1 & 382 & 83 & 95 & 2 & 44 & 80 \\
\hline Average or total.. & & 3 & 159 & 77.1 & 95.9 & 1.9 & 44 & 75.7 \\
\hline \multirow[t]{4}{*}{$-\mathrm{P}$} & 5 & 0 & 0 & .. & . & .. & . & .. \\
\hline & 6 & 2 & 361 & 57 & 92 & 6 & 58 & 56 \\
\hline & 7 & 1 & 316 & 37 & 85 & 45 & 41 & 51 \\
\hline & 9 & 2 & 282 & 48 & 95 & 34 & 38 & 59 \\
\hline Average or total. & & 5 & 320 & 50.3 & 92.2 & 23.4 & 41.4 & 56.2 \\
\hline \multirow[t]{4}{*}{$-\mathrm{K}$} & 5 & 2 & 340 & 26 & 89 & 0 & . & 24 \\
\hline & 6 & 3 & 105 & 30 & 85 & 0 & 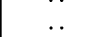 & 26 \\
\hline & 7 & 2 & 422 & 65 & 81 & 5 & 100 & 60 \\
\hline & 9 & 2 & 522 & 84 & 91 & 10 & 82 & 85 \\
\hline Average or total. & & 9 & 320 & 58.9 & 87.3 & 5.1 & 87.2 & 56.7 \\
\hline \multirow[t]{4}{*}{$-\mathrm{Ca}$} & 5 & 3 & 163 & 72 & 53 & 16 & 20 & 42 \\
\hline & 6 & 3 & 370 & 55 & 71 & 19 & 17 & 43 \\
\hline & 7 & 2 & 314 & 53 & 83 & 26 & 31 & 56 \\
\hline & 9 & 2 & 240 & 57 & 71 & 29 & 38 & 54 \\
\hline Average or total. & & 10 & 269 & 58.1 & 69.7 & 21.8 & 25.9 & 47.0 \\
\hline
\end{tabular}

The more severe the deficiency of nitrogen, the greater was the percentage of red cotyledon after three years of storage. At four years, the greater deficiency of $\mathrm{K}$ appeared to have caused a greater loss of germination than had the lesser deficiency of $\mathrm{K}$. Again there was no evidence of any difference in seed germination among successive harvests from the same plant. 


\section{Experiments with Peppers}

California Wonder pepper seed (Ferry-Morse Seed Co.) was used in the pepper experiments.

First Experiment, 1951-1952. The seed was planted in the crocks on September 7, 1951. The plants were thinned to one per crock when they were 1 inch tall. As with the carrot experiments, there were five groups of five crocks each. The deficiency treatments $(-\mathrm{N},-\mathrm{P},-\mathrm{K},-\mathrm{Ca})$ were begun on September 7, October 13, October 19, October 26, and November 3. No fruits matured on the plants in deficiency treatments starting on September 7. The plants in the other groups received a complete solution until the deficiency treatments were begun, five, six, seven, and nine weeks after the seed was sown.

The only fruits harvested were those that were completely red (or orange on the $-\mathrm{K}$ plants) and beginning to wrinkle. Harvest was on January 31, 1952.

Results are given in table 5. The abnormal seeds were those that showed a black embryo through seedcoats varying from normal white through shades of tan to brown. Seeds that appeared to have no embryo or endosperm were recorded as empty, and those that looked like a shriveled brown flake were considered aborted. Since there was a gradation from normal to empty and aborted seeds, some of the borderline seeds in the empty and aborted classification germinated (fewer than 1 per cent). The intent, however, was to include in this classification only seeds that would not germinate. This experiment was terminated when only two or three fruits per plant had ripened.

Second Experiment, 1952. Seed for the second pepper experiment was sown on February 13, 1952. Final harvest was on June 27, 1952. All the plants that were to receive a deficient solution were first given a complete solution for various periods -30 days for $-\mathrm{P}$ and $-\mathrm{Ca}, 35$ days for $-\mathrm{K}$, and 40 days for $-\mathrm{N}$. They later received only the $-\mathrm{N},-\mathrm{P},-\mathrm{K}$, or $-\mathrm{Ca}$ solution. Each treatment consisted of five single-plant replications.

Mature fruits of the $-\mathrm{K}$ plants were orange; the others were the usual red. The $-\mathrm{P}$ fruits were long (table 6 ), with a deep depression at the stem end; the $-\mathrm{K}$ fruits were wider than they were long, and were flat at the stem end. Table 6 also indicates that the $-\mathrm{N},-\mathrm{K}$, and -Ca fruits were smaller than those from plants receiving the complete treatment.

Over 6 per cent of the seeds from the $-\mathrm{K}$ fruits had germinated in the fruits before harvest. In some fruits the germination was especially striking-a solid mass of radicles and hypocotyls when the fruits were cut open. Occasionally seeds sprouted in fruits from the other treatments, but these few seedlings showed only 1 to $2 \mathrm{~mm}$ of the radicle protruding. This was quite different from the fully germinated seeds found in many of the $-\mathrm{K}$ fruits. Percentage of normal seeds was much less in the $-\mathrm{N},-\mathrm{K}$, and $-\mathrm{Ca}$ fruits than in fruits from plants receiving either complete or $-\mathrm{P}$ solutions.

Germination of the normal seeds was more or less similar, regardless of treatment (table 6 ). In the $-\mathrm{N},-\mathrm{K}$, and $-\mathrm{Ca}$ treatments the high proportion of abnormal seed with lower germination, and of empty and aborted seed 


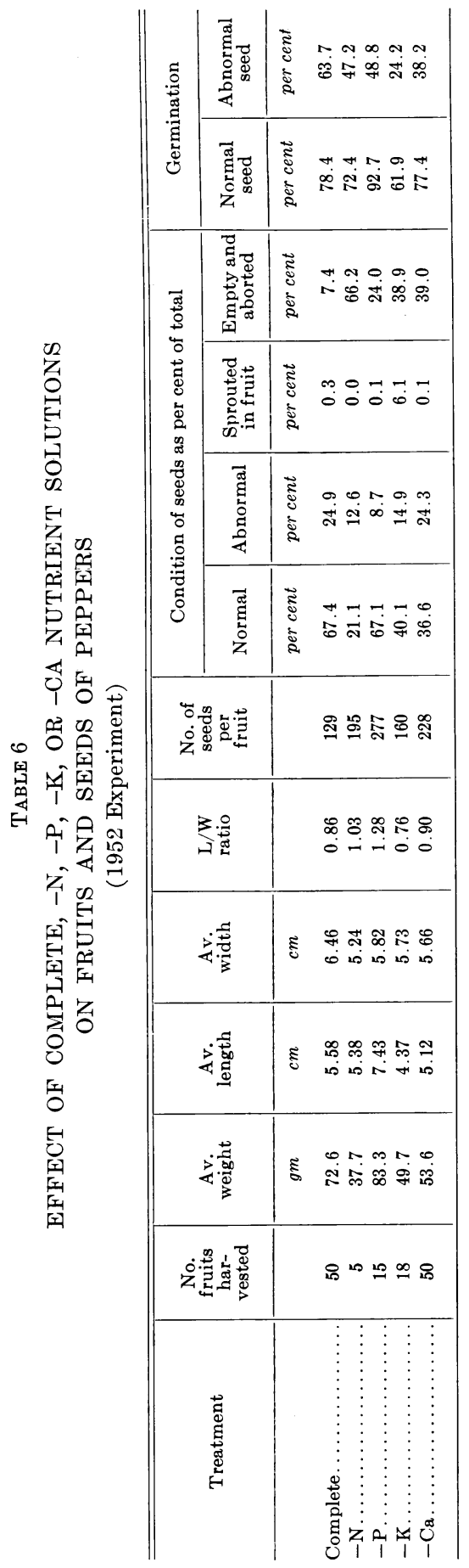


with no germination, resulted in a highly significant lower average germination of all of the seeds in these treatments. These data were analyzed both on a straight percentage basis and on a conversion to are sine, with the same treatments being significantly different. The results were as follows:

\begin{tabular}{|c|c|}
\hline TREATMENT & $\begin{array}{l}\text { WEIGHTED AVERAGE } \\
\text { GERMINATION* } \\
\text { Per cent }\end{array}$ \\
\hline Complete & 68.8 \\
\hline$-\mathrm{N}$ & 21.3 \\
\hline$-\mathrm{P}$ & . 66.5 \\
\hline$-\mathrm{K}$ & 28.6 \\
\hline$-\mathrm{Ca}$ & 37.8 \\
\hline
\end{tabular}

* L.S.D. at $19: 1,27.84$; at $99: 1,38.34$.

Third Experiment, 1952-1953. The third pepper experiment was performed exactly as was the second. The seed was planted on July 9, 1952, and final harvest was on February 4, 1953.

Again, all mature fruits of the five potassium-deficient plants were orange. The length-width ratio, determined for each fruit, averaged close to 1.0, with no apparent differences among treatments.

Table 7 shows that the $-\mathrm{N}$ plants produced few fruits. The -Ca plants produced more, but smaller fruits than did the check plants. All deficiency treatments resulted in fewer seeds per fruit than did the complete treatment. Percentage of normal seeds was lowest in the $-\mathrm{N},-\mathrm{K}$, and $-\mathrm{Ca}$ treatments. In the $-\mathrm{K}$ plants, over 40 per cent of the seeds germinated in the fruit-a striking effect. A few seeds sprouted in fruits in other treatments, but in each case the development was very slight, restricted to emergence of the radicle by $0.5 \mathrm{~cm}$ or less. On the other hand, most of the germinated seed in the $-\mathrm{K}$ fruits had radicles, and hypocotyls 2 to $4 \mathrm{~cm}$ long, and many had green cotyledons separated from the seed coats.

Table 8 gives the germination of seeds at harvest and after six years at room temperature.

Fourth Experiment, 1955-1956. The fourth pepper experiment was begun on October 17, 1955. The first ripe fruits were harvested on January 23, 1956, and the last ones on September 1, 1956, the end of the experiment. The harvest was extended over a long period in an attempt to determine if seeds from late-harvested fruits produced under nutrient-deficient conditions germinated differently from seeds of early fruits. The experiments on lettuce and carrots, as well as those on peppers, had shown no differences between early- and late-harvested seed, but none of the previous experiments had had such a long harvest period.

Two plants were used per treatment, and the same nutrient solution mixture was applied to a given plant throughout the experiment. The solutions applied were mixtures of minus nutrient solutions $(-\mathrm{N},-\mathrm{P},-\mathrm{K}$, or $-\mathrm{Ca})$ with the complete solution in three proportions, as follows:

\begin{tabular}{|c|c|c|c|}
\hline \multirow{2}{*}{$\begin{array}{c}\text { NUTRIENT } \\
-\mathrm{N} .\end{array}$} & \multicolumn{3}{|c|}{ PROPORTION MINUS : COMPLETE NUTRIENT } \\
\hline & $15: 1$ & $31: 1$ & $63: 1$ \\
\hline$-P$ & $31: 1$ & $63: 1$ & $127: 1$ \\
\hline$-\mathrm{K}$ & $3: 1$ & $7: 1$ & $15: 1$ \\
\hline$-\mathrm{Ca}$ & $7: 1$ & $15: 1$ & $31: 1$ \\
\hline
\end{tabular}


TABLE 7

EFFECT OF COMPLETE, $-\mathrm{N},-\mathrm{P},-\mathrm{K}$, OR -CA NUTRIENT SOLUTIONS ON NUMBER OF FRUITS, AVERAGE FRUIT WEIGHT, AND CONDITION OF SEEDS IN PEPPERS

(1952-1953 Experiment)

\begin{tabular}{|c|c|c|c|c|c|c|c|}
\hline Treatment & $\begin{array}{l}\text { No. } \\
\text { fruits } \\
\text { har- } \\
\text { vested }\end{array}$ & $\begin{array}{l}\text { Av. } \\
\text { fruit } \\
\text { wt. }\end{array}$ & $\begin{array}{l}\text { Av. no. } \\
\text { of seeds } \\
\text { per fruit }\end{array}$ & \multicolumn{4}{|c|}{ Condition of seed } \\
\hline & & $g m$ & & per cent & per cent & per cent & per cent \\
\hline$-\mathrm{N} \ldots \ldots \ldots$ & 9 & 52.1 & 181 & 19.8 & 21.1 & 0.4 & 58.6 \\
\hline$-P \ldots$ & 18 & 83.3 & 254 & 76.7 & 6.9 & 1.5 & 14.8 \\
\hline$-\mathrm{K}$. & 19 & 61.2 & 234 & 15.7 & 25.9 & 41.6 & 16.9 \\
\hline -Ca. & 33 & 37.0 & 173 & 38.5 & 23.2 & 0.8 & 37.5 \\
\hline
\end{tabular}

TABLE 8

EFFECT OF COMPLETE, $-\mathrm{N},-\mathrm{P},-\mathrm{K}$, OR -CA NUTRIENT SOLUTIONS ON NUMBER AND GERMINATION PERCENTAGE OF NORMAL PEPPER SEED AT HARVEST AND AFTER SIX YEARS

(1952-1953 Experiment)

\begin{tabular}{|c|c|c|c|c|c|c|}
\hline \multirow{2}{*}{ Treatment } & \multicolumn{3}{|c|}{1953} & \multicolumn{3}{|c|}{1959} \\
\hline & $\begin{array}{l}\text { No. fruits } \\
\text { tested }\end{array}$ & $\begin{array}{l}\text { No. normal } \\
\text { seeds }\end{array}$ & $\begin{array}{l}\text { Germination } \\
\text { of normal seed }\end{array}$ & $\begin{array}{l}\text { No. fruits } \\
\text { tested }\end{array}$ & $\begin{array}{l}\text { No. normal } \\
\text { seeds }\end{array}$ & $\begin{array}{c}\text { Germination } \\
\text { of normal seed }\end{array}$ \\
\hline & & & per cent & & & per cent \\
\hline Complete. & 2 & 114 & 86.0 & 22 & 5,507 & 30.0 \\
\hline$-\mathrm{N}$ & . & $\ldots$ & $\ldots$ & 7 & 318 & 0.0 \\
\hline$-P$. & 5 & 834 & 80.3 & 15 & 2,941 & 6.2 \\
\hline$-\mathrm{K}$. & 6 & 169 & 33.7 & 12 & 512 & 7.0 \\
\hline$-\mathrm{Ca} \ldots$ & 12 & 460 & 63.5 & 18 & 1,542 & 38.5 \\
\hline
\end{tabular}

With this method, seeds did not sprout within the fruits of pepper plants deficient in potassium. In the previous experiments in which sprouting occurred, the nutrient solution was a complete solution succeeded by one entirely lacking in potassium. In this experiment, on the other hand, the plants received a low level of potassium continuously. Mature fruits from the lowpotassium treatments were again orange rather than red.

The sharp decline in number of fruits per plant as each deficiency was made more severe is clearly apparent in table 9 . For example, the two plants receiving the complete solution had a total of 59 fruits, whereas the plants receiving a $-\mathrm{K}$ and complete solution in the proportions $3: 1,7: 1$, and 15:1 had respectively 33,13 , and 5 fruits. The number of seeds per fruit varied, with the fruits from most treatments averaging about 100 seeds each.

Germination figures are given in table 10. 
Table 11 compares seed from fruit harvested during the first half of the experiment with that from the second half. The latter had a lower germination than the former, but the decrease was no greater from the deficiency treatments than from the complete treatment, with one exception-germination of normal seeds dropped from 79 to 0 per cent in the most severe potassium-deficient treatment.

TABLE 9

EFFECT OF COMPLETE, $-\mathrm{N},-\mathrm{P},-\mathrm{K}$, OR -CA NUTRIENT SOLUTIONS ON NUMBER OF FRUITS PER PLANT, NUMBER OF SEEDS PER PLANT AND PER FRUIT, AND PERCENTAGE OF NORMAL, ABNORMAL, OR ABORTED PEPPER SEEDS

(1955-1956 Experiment)

\begin{tabular}{|c|c|c|c|c|c|}
\hline \multirow{2}{*}{ Treatment } & \multirow{2}{*}{$\begin{array}{l}\text { No. fruits } \\
\text { harvested }\end{array}$} & \multirow{2}{*}{$\begin{array}{l}\text { No. seeds } \\
\text { per fruit }\end{array}$} & \multicolumn{3}{|c|}{ Condition of seeds } \\
\hline & & & Normal & Abnormal & $\begin{array}{c}\text { Aborted } \\
\text { or empty }\end{array}$ \\
\hline Complete.... & 59 & 108 & $\begin{array}{c}\text { per cent } \\
70\end{array}$ & $\begin{array}{c}\text { per cent } \\
3\end{array}$ & $\begin{array}{c}\text { per cent } \\
27\end{array}$ \\
\hline $\begin{array}{cc}-\mathrm{N} & 15: 1 \ldots \ldots \ldots \ldots \ldots \ldots \ldots \ldots \ldots \\
& 31: 1 \ldots \ldots \ldots \ldots \ldots \ldots \ldots \ldots \ldots \ldots \\
& 63: 1 \ldots \ldots \ldots \ldots \ldots \ldots \ldots\end{array}$ & $\begin{array}{l}8 \\
5 \\
5\end{array}$ & $\begin{array}{r}65 \\
131 \\
75\end{array}$ & $\begin{array}{l}50 \\
51 \\
17\end{array}$ & $\begin{array}{l}9 \\
6 \\
1\end{array}$ & $\begin{array}{l}41 \\
43 \\
82\end{array}$ \\
\hline Average..... & 6 & 86 & 42 & 6 & 52 \\
\hline 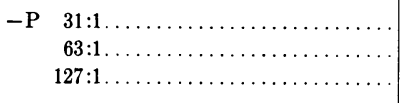 & $\begin{array}{l}20 \\
21 \\
10\end{array}$ & $\begin{array}{r}136 \\
67 \\
104\end{array}$ & $\begin{array}{l}57 \\
75 \\
77\end{array}$ & $\begin{array}{l}1 \\
1 \\
3\end{array}$ & $\begin{array}{l}42 \\
24 \\
20\end{array}$ \\
\hline$\ldots \ldots \ldots \ldots \ldots \ldots$ & 17 & 101 & 66 & 1 & 33 \\
\hline 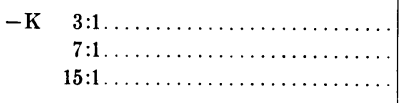 & $\begin{array}{r}33 \\
13 \\
5\end{array}$ & $\begin{array}{l}111 \\
160 \\
101\end{array}$ & $\begin{array}{l}62 \\
38 \\
27\end{array}$ & $\begin{array}{l}6 \\
1 \\
2\end{array}$ & $\begin{array}{l}32 \\
61 \\
71\end{array}$ \\
\hline Average $\ldots \ldots \ldots \ldots \ldots \ldots$ & 17 & 123 & 52 & 4 & 44 \\
\hline 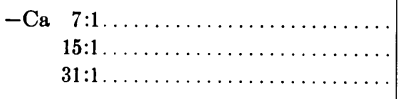 & $\begin{array}{l}47 \\
40 \\
29\end{array}$ & $\begin{array}{r}128 \\
89 \\
90\end{array}$ & $\begin{array}{l}42 \\
48 \\
17\end{array}$ & $\begin{array}{l}21 \\
15 \\
25\end{array}$ & $\begin{array}{l}37 \\
37 \\
58\end{array}$ \\
\hline Average...... & 39 & 105 & 38 & 21 & 41 \\
\hline
\end{tabular}

\section{RESULTS AND DISCUSSION}

The discussion presents the trends, shown in a series of experiments, in terms of individual nutrient deficiencies.

\section{Nitrogen Deficiency}

Nitrogen deficiency resulted in an extremely low yield of fruit and seed. The commercial seeds of carrot and lettuce are really one-seeded fruits. In every experiment these, along with pepper fruits, were smaller and lighter than the controls. In addition, the number of fruits per plant was much less. The number of seed in the pepper fruit was less in three of four experi- 
ments, as was the percentage of normal seed. In two pepper experiments the percentages of normal seed in nitrogen-deficient fruit were only 20 and 21, as compared with 68 and 67 in the controls. Yet when this low yield of normal seed was germinated, percentage of germination was essentially the same as that of seed from the complete nutrient treatments. Germination after storage gave variable results, but seed from $-\mathrm{N}$ plants tended to decline in germination faster than did seed from the controls.

TABLE 10

EFFECT OF COMPLETE, -N, -P, -K, OR -CA NUTRIENT SOLUTIONS ON AVERAGE GERMINATION OF NORMAL, ABNORMAL, AND TOTAL PEPPER SEEDS (INCLUDING ABORTED) AT HARVEST AND AFTER THREE YEARS AT ROOM TEMPERATURE (1955-1956 Experiment)

\begin{tabular}{|c|c|c|c|c|}
\hline \multirow{2}{*}{ Treatment } & \multicolumn{3}{|c|}{ At harvest } & \multirow{2}{*}{$\begin{array}{c}\text { After three } \\
\text { years' storage }\end{array}$} \\
\hline & $\begin{array}{l}\text { Normal seed } \\
\text { germination }\end{array}$ & $\begin{array}{c}\text { Abnormal seed } \\
\text { germination }\end{array}$ & $\begin{array}{c}\text { Total seed } \\
\text { germination }\end{array}$ & \\
\hline Complete......... & $\begin{array}{c}\text { per cent } \\
89\end{array}$ & $\begin{array}{c}\text { per cent } \\
66\end{array}$ & $\begin{array}{c}\text { per cent } \\
64\end{array}$ & $\begin{array}{c}\text { per cent } \\
94\end{array}$ \\
\hline $\begin{array}{c}15: 1 \ldots \ldots \ldots \ldots \ldots \ldots \ldots \ldots \ldots \ldots \\
31: 1 \ldots \ldots \ldots \ldots \ldots \ldots \ldots \ldots \ldots \ldots \\
63: 1 \ldots \ldots \ldots \ldots \ldots \ldots \ldots \ldots \ldots \ldots\end{array}$ & $\begin{array}{l}63 \\
82 \\
97\end{array}$ & $\begin{array}{r}8 \\
24 \\
40\end{array}$ & $\begin{array}{l}32 \\
43 \\
17\end{array}$ & $\begin{array}{l}\text { no seed } \\
\text { no seed } \\
\text { no seed }\end{array}$ \\
\hline Average...$\ldots \ldots$ & 76 & 17 & 33 & . \\
\hline 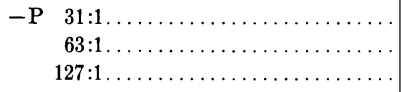 & $\begin{array}{l}83 \\
91 \\
89\end{array}$ & $\begin{array}{r}37 \\
0 \\
32\end{array}$ & $\begin{array}{l}46 \\
64 \\
68\end{array}$ & $\begin{array}{l}90 \\
90 \\
91\end{array}$ \\
\hline Average. . & 87 & 33 & 55 & 90 \\
\hline 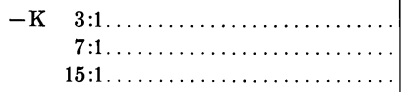 & $\begin{array}{l}74 \\
80 \\
78\end{array}$ & $\begin{array}{l}67 \\
40 \\
17\end{array}$ & $\begin{array}{l}50 \\
28 \\
20\end{array}$ & $\begin{array}{l}92 \\
96 \\
54\end{array}$ \\
\hline Average. . & 76 & 63 & 40 & 92 \\
\hline 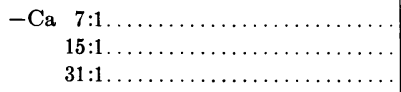 & $\begin{array}{l}74 \\
70 \\
66\end{array}$ & $\begin{array}{r}20 \\
18 \\
7\end{array}$ & $\begin{array}{l}35 \\
35 \\
13\end{array}$ & $\begin{array}{l}76 \\
57 \\
79\end{array}$ \\
\hline Average ....... & 72 & 16 & 30 & 63 \\
\hline
\end{tabular}

* Only normal seed remained to be tested in 1959 .

\section{Phosphorus Deficiency}

A deficiency of phosphorus had less effect on the seed obtained than did any of the other nutrients tested. In fact, other than less fruit per plant in every experiment, there was no consistent difference between the seeds from the phosphorus-deficient plants and those from the plants receiving the complete nutrient. The percentage of normal seed, and its germination at harvest and after storage were comparable with the control. 


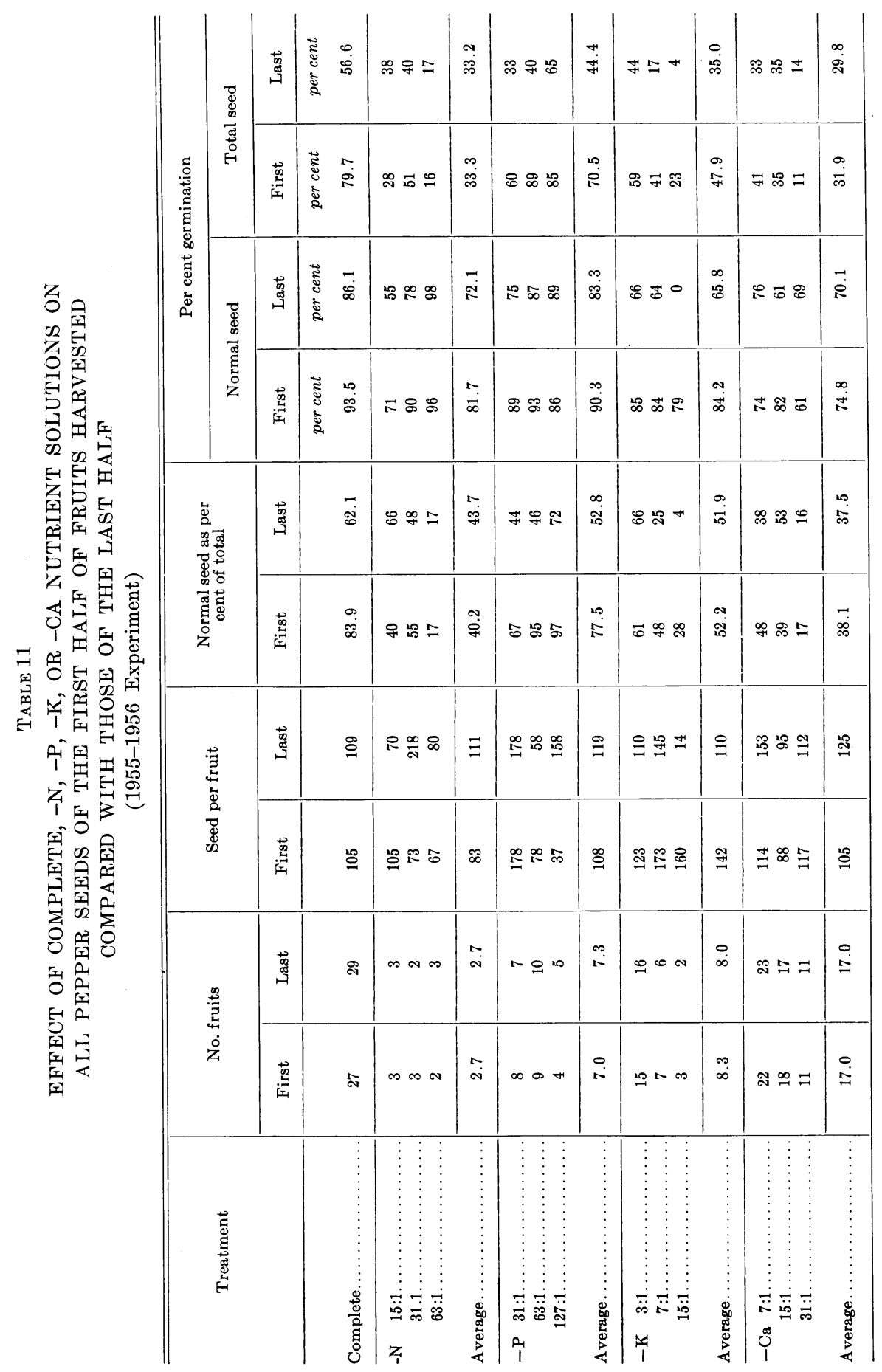




\section{Potassium Deficiency}

One of the most unusual results was the sprouting of seeds in pepper fruits when the nutrient solution was changed from complete to one lacking potassium. In contrast, no sprouting occurred in the one pepper experiment where the potassium deficiency was produced with a solution containing a low level of potassium supplied continuously. Iwata and Eguchi (1958) reported that some seeds of Chinese cabbage plants deficient in potassium germinated in the seed pods on the plant. Thus, potassium may be necessary to the formation of a germination-inhibiting compound, or it may be that potassium deficiency brings about formation of a substance promoting germination. Whichever the cause, it appears that complete lack of potassium permits sprouting in the pepper fruit.

Percentage of normal seeds was low in pepper fruits deficient in potassium. Germination at harvest was lower than that of controls in all carrot experiments, but in only one pepper experiment. This did not hold true with the lettuce seed. In all experiments in which seed was stored, however, seed from potassium-deficient plants deteriorated faster than did seed from the control plants. It thus seems clear that potassium deficiency reduces the longevity of seed.

On all potassium-deficient pepper plants the fruits were orange at maturity rather than red, indicating that potassium may play a role in lycopin formation.

\section{Calcium Deficiency}

A deficiency of calcium seriously affected the seed produced. The percentage and germination of normal seed were less than for the controls. During storage the seed declined in germination faster than did seed from plants receiving complete solution. A deficiency of calcium was more harmful to seed than any other deficiency tested.

\section{SUMMARY}

Plants of carrot, lettuce, and pepper were grown in sand cultures receiving either a complete nutrient solution or one deficient in $\mathrm{N}, \mathrm{P}, \mathrm{K}$, or Ca.

The deficiencies ranged from mild to one so severe that plants died. An effort was made to produce a severe deficiency, but not such that no seeds were produced.

Plant symptoms resulting from the different deficiencies included necrosis of the growing tips of calcium-deficient plants and necrotic spots along the leaf margins of potassium-deficient plants.

Seeds germinated within pepper fruits if the potassium deficiency was created by changing the nutrient solution abruptly from a complete one to one containing no potassium.

Seed yields were always depressed by low N, P, K, or Ca treatments. The percentage of normal seeds was depressed by low $\mathrm{N}, \mathrm{K}$, or Ca, but not by low P.

At harvest time, germination of normal seeds from the low $\mathrm{N}$ and $\mathrm{P}$ treatments was usually no different from that of seeds from the complete solution 
treatment, but $\mathrm{K}$ deficiency resulted in a lower germination in some experiments and $\mathrm{Ca}$ deficiency resulted in lower germination in the carrot and pepper experiments.

In storage, seeds from the low $\mathrm{K}$ and $\mathrm{Ca}$ treatments declined in germination faster than did seeds from the complete-solution treatments.

\section{LITERATURE CITED}

Dempsey, Wesley H., and James F. Harrington

1951. Red cotyledon of lettuce. California Agriculture 5(7):4.

Eguchi, Tsuneo

1960. Influence of nitrogenous fertilizer applied at different stages on seed production in cabbage and Chinese cabbage. Proc. Amer. Soc. Hort. Sci. (In press.)

Fox, Robert L., and William A. Albrecht

1957. Soil fertility and the quality of seeds. Missouri Agr. Exp. Sta. Res. Bul. 619.

HARTWELL, B. L.

1932. The influence of fertilizers on crop quality. National Fertilizer Assoc. Proc. 811: 1-60. 389 Ref.

Hawthorn, L. R., and L. H. Pollard

1956. Production of lettuce seed as affected by soil moisture and fertility. Utah Agr. Exp. Sta. Bul. 386.

Hoagland, D. R., and D. I. ARnoN

1950. The water-culture method for growing plants without soil. California Agr. Exp. Sta. Cir. 347. (Rev.)

IwATA, M., and Y. EGUCHI

1958. Effects of phosphorus and potassium supplied for the various stages of growth, on the yield and quality of seeds of Chinese cabbage. Jour. Hort. Assn. Japan 27 : 171-78. (In Japanese, English summary.)

JAMES, EDwIN, and T. A. BANCROFT

1951. The use of half-plants in a balanced incomplete block in investigating the effect of calcium, phosphorus, and potassium, at two levels each, on the production of hard seed in crimson clover, Trifolium incarnatum. Agron. Jour. 43(2) :96-98. Pendleton, R. A.

1954. Cultural practices related to yields and germination of sugar beet seed. Proc. Amer. Sugar Beet Tech., 1954. 157-60.

Person, A. E., and K. C. Berger

1950. Effect of magnesium on the quality and yield of canning peas. Soil Sci. Soc. Proc. $15: 205-08$.

SCHUdEL, H. L.

1952. Vegetable seed production in Oregon. Oregon Agr. Exp. Sta. Bul. 512. 

The journal Hilgardia is published at irregular intervals, in volumes of about 600 pages. The number of issues per volume varies.

Subscriptions are not sold. The periodical is sent as published only to libraries, or to institutions in foreign countries having publications to offer in exchange.

You may obtain a single copy of any issue free, as long as the supply lasts; please request by volume and issue number from:

Agricultural Publications

207 University Hall

2200 University Avenue

University of California

Berkeley 4, California

The limit to nonresidents of California is 10 separate issues on a single order. A list of the issues still available will be sent on request.

In our publications it is sometimes convenient to use trade names of products or equipment rather than scientific identifications. In so doing it is unavoidable in some cases that similar products which are on the market under other trade names may not be cited. No endorsement of named products is intended nor is criticism implied of similar products which are not mentioned. 